\title{
Giant cell tumour associated with rheumatoid arthritis
}

\author{
ANTONIO REGINATO, ${ }^{*} \dagger$ VIRGINIA MARTINEZ, ${ }^{*}$ H. RALPH SCHUMACHER, $\dagger$ \\ AND JOSE TORRES* \\ From the Arthritis Section, Departments of Medicine, Pathology, and Surgery, San Juan de Dios Hospital \\ and University of Chile, Santiago, Chile, ${ }^{*}$ the Arthritis Section, Department of Medicine, University of \\ Pennsylvania School of Medicine, and the Veterans Administration Hospital, Philadelphia, Pennsylvania $\dagger$
}

Pigmented villonodular synovitis is commonly considered in the differential diagnosis of chronic monoarticular joint disease (Rodnan, 1966). Some authors have considered it a neoplasm (Bennett, 1950; Wright, 1951), while others believe it is a chronic inflammatory process of unknown aetiology (Jaffe, Lichtenstein, and Sutro, 1941). A histologically identical process localized to a single nodular tumourlike mass in one portion of a joint or tendon sheath has variously been termed giant cell tumour of the tendon sheaths, fibrous xanthoma of synovium, or nodular pigmented villonodular synovitis (Byers, Cotton, Deacon, Lowy, Newman, Sissons, and Thompson, 1968; Galloway, Broders, and Ghormley, 1940; Jones, Soule, and Coventry, 1969; Larmon, 1965). The purpose of this report is to document 5 instances of the association of rheumatoid arthritis and giant cell tumour of the tendon sheaths or joint.

\section{Materials and methods}

Four patients with classical rheumatoid arthritis (RA) and one patient with definite RA by the A.R.A. criteria (Ropes, Bennett, Cobb, Jacox, and Jessar, 1959) with giant cell tumours of the tendon sheaths of the hand have been studied in the Arthritis Clinic of the San Juan de Dios Hospital, Santiago, Chile, from April 1969 to December 1972. All tumours fulfilled the criteria for giant cell tumour or nodular villonodular synovitis of the tendon sheaths as described by Jaffe and others (1941).

Samples of all tumours were fixed in buffered formalin and sections were examined by light microscopy after haematoxylin and eosin, van Gieson, Sudan III, and Perls's (iron) stains. For electron microscopy the tumour specimen was placed immediately in formaldehyde-glutaraldehyde fixative (Karnovsky, 1965) diluted 1:1 with 0.1 $\mathrm{mol} / 1$. cacodylate buffer at $\mathrm{pH} 7 \cdot 4$, and processed with a technique previously reported (Schumacher, 1968).

Cases 1 to 3 had Parker-Pearson needle biopsies of the knee synovium (Schumacher and Kulka, 1972).

\section{Case reports}

\section{CASE 1}

A 65-year-old white woman one year before admission noted progressive symmetrical polyarthritis with involvement of distal and proximal interphalangeal (DIP, PIP) joints, metacarpophalangeal (MCP) joints, shoulders, knees, and ankles. She was treated at another hospital with prednisone $20 \mathrm{mg}$ daily, with some slight improvement of her joint inflammation; but 6 months before admission she noticed prominent swelling extending beyond the joint space superimposed on the previously inflamed right third PIP joint. This was not associated with more severe inflammation in other joints.

Three months before her admission, coincidental with a severe flare-up of her polyarthritis, she developed multiple subcutaneous nodules and painful redness of both eyes with progressive loss of vision.

Physical examination revealed a chronically ill patient who was unable to walk due to severe active polyarthritis. Subcutaneous nodules were palpated on the occipital area, helix of the right ear, dorsal aspect of both second MCP joints, knees, and lateral malleoli. Painless lymph nodes about $1 \mathrm{~cm}$ in diameter were palpable in both axillae. There was almost complete loss of vision, thinning of sclerae, episcleral nodules, and signs of anterior uveitis. There was mild hepatomegaly and splenomegaly. Joint examination revealed tender thickening of the synovium with limitation of range of motion of wrists and PIP joints. There was subluxation of the PIPs of both thumbs. There was a diffuse, soft, symmetrical, well-demarcated, very large, nonfluctuant swelling of the right third PIP joint extending beyond the joint to the proximal and distal phalanges. There was shiny skin, increase in local temperature, and hyperpigmentation (Fig. 1). The right knee was swollen with a small effusion and painful limitation of full flexion. The motion of shoulders, hips, and cervical spine was painful and restricted.

Laboratory studies included a haematocrit of $31 \%$, white cell count of $11,700 / \mathrm{mm}^{3}$ with basophils $2 \%$, eosinophils $12 \%$, neutrophils $71 \%$, lymphocytes $13 \%$, and monocytes $2 \%$. The Westergren erythrocyte sedimentation rate was $65 \mathrm{~mm} / \mathrm{hr}$ and the total protein was 


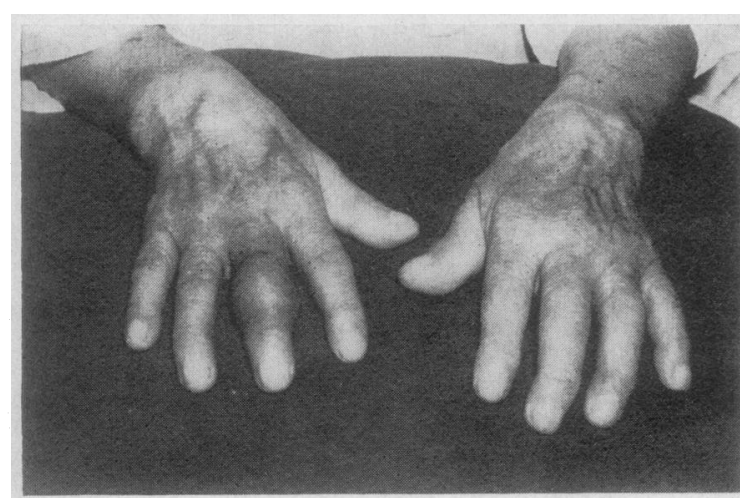

FIG. 1 Case 1. Diffuse soft nonfluctuant swelling of the right third PIP joint involving two-thirds of the proximal and distal phalanges, with shiny skin and hyperpigmentation. Synovial thickening of DIP, PIP, MCP joints and wrists can also be seen

$6.2 \mathrm{~g} / 100 \mathrm{ml}$ (albumin $2.9 \mathrm{~g}$ and globulin $3.3 \mathrm{~g}$ ). Serum protein electrophoresis showed albumin $32.5 \%, \alpha_{1}$ globulin $6.5 \%, \alpha_{2}$-globulin $11 \%, \beta$-globulin $15 \%$, and $\gamma$-globulin $35 \%$. Serum latex fixation test for rheumatoid factor was persistently negative, using Hyland slide and tube dilution test (Singer and Plotz, 1956). There were no LE cells nor antinuclear antibodies. Serum uric acid, calcium, phosphorus, alkaline phosphatase, bone marrow aspiration, and chest film were normal. Roentgenograms of the joints showed diffuse demineralization with narrowing of the joint space and bilateral juxta-articular erosions of PIPs and DIPs, wrist, and fifth metatarsophalangeal joints. There was subluxation of the PIPs of both thumbs. There was bilateral erosion of the styloid process of the ulna and the lateral end of both clavicles. The right third PIP joint showed diffuse soft tissue swelling with extensive irregular osteolytic lesions of the phalanges (Fig. 2A).

From the right knee, $2 \mathrm{ml}$ of a cloudy synovial fluid were aspirated. Analysis of synovial fluid revealed poor viscosity; acetic acid test for mucin was grade 3 (poor); white cell count $11,000 / \mathrm{mm}^{3}$ with $38 \%$ polymorphonuclears, $42 \%$ monocytes, and $20 \%$ large mononuclear cells with homogeneous blue-stained cytoplasm resembling type B synovial cells (Kinsella, Baum, and Ziff, 1970). On wet smear $38 \%$ of the cells had intracytoplasmic inclusion bodies. There were no crystals. A needle synovial biopsy of the same knee disclosed fibrous synovium with mild hyperplasia of the synovial lining cells and infiltration by lymphocytes and mononuclear cells. The histological examination of a subcutaneous nodule showed a typical rheumatoid nodule, with a central area of fibrinoid necrosis surrounded by a palisade of epithelioid cells. The liver was shown to be normal by a percutaneous biopsy. An axillary lymph node revealed signs of reactive follicular hyperplasia.

The histological study of the open biopsy of the right third PIP joint showed the presence of a tumour consisting predominantly of large, pale polyhedral, irregular or rounded, cells with abundant cytoplasm. Numerous cells had foamy cytoplasm. Sudan III stain revealed the presence of fat in these cells; a few had a golden brown pigment in coarse clumps which was shown to be haemosiderin by Perls's stain. A large number of multinucleated

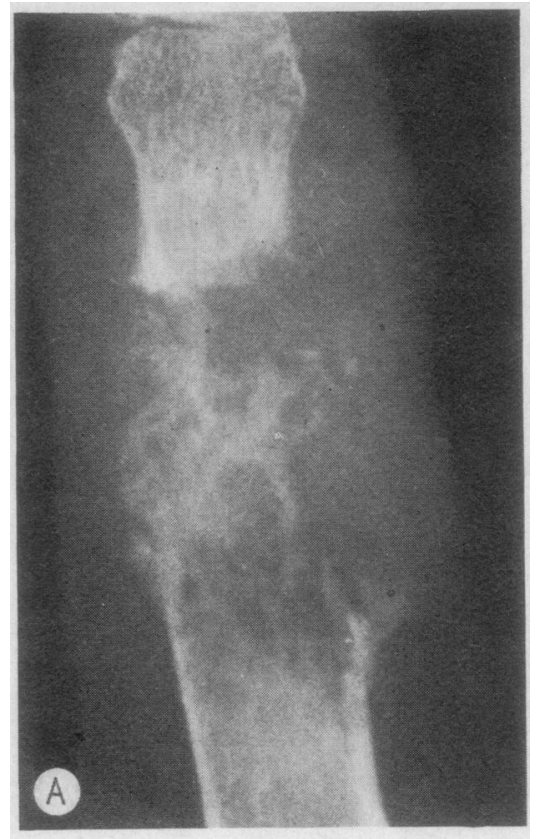

FIG. 2 Roentgenograms of Case 1. (A) Complete destruc- $\stackrel{\Phi}{\varrho}$ tion of the right third PIP joint with extensive osteolysis of the phalanges. (B) Films taken after 2 years of observation showing absence of the right third finger, bone ankylosis of 8 the right fourth PIP joint, and narrowing of the MCP joint space 
giant cells were present (Fig. 3). Amputation of the right third finger was performed. A yellowish tissue mass involving the proximal third of the second phalanx, the interphalangeal joint, and most of the proximal phalanx was observed. The joint space had almost disappeared; a fibrin pannus completely filled the cleft. The invasive mass when examined histologically showed more foam cells than were seen in the earlier biopsy; there were scanty giant cells and a few haemosiderin-laden histiocytes.

The patient was treated with gold therapy and prednisone $30 \mathrm{mg}$ daily for 4 weeks, and the corticosteroid was then slowly reduced to a maintenance dose of $7.5 \mathrm{mg}$ daily. After 2 years of treatment there was a definite improvement in her general condition and physical signs of eye and joint inflammation. There was complete resolution of the subcutaneous nodules, enlarged lymph nodes, and splenomegaly. Serial roentgenograms revealed progression of the erosions of the DIP joints, wrists, and acromioclavicular joints, and new erosions at the PIPs with bony ankylosis of the left fourth DIP and right fourth PIP (Fig. 2B). Surgical biopsy of an erosive bone lesion of the styloid process of the left ulna showed osteoporosis with a rheumatoid type granuloma, small osteolytic foci, and osteogenic regenerative activity. No villonodular synovitis was observed.
CASE 2

A 60-year-old white female had a 10-year history of classical rheumatoid arthritis. A circumscribed, firm, nontender nodule without increased heat or erythema was present on the radial aspect of the left second PIP for 4 years before the diagnosis of giant cell tumour of tendon sheaths was established (Fig. 4). The left second PIP joint swelling was considered for a long time as part of the rheumatoid inflammation, but finally its asymmetrical growth and the increasing cystic destruction of the proximal phalanx suggested the presence of another process (Fig. 5A). The surgical biopsy showed a tumour formed by large mononuclear cells located in small clefts, xanthomatous histiocytes, haemosiderin-laden macrophages, multinucleated giant cells, and an abundant stroma of connective tissue with fibroblasts (Fig. 6). By electron microscopy the tumour was predominantly formed of type B and intermediate cells (Barland, Novikoff, and Hamerman, 1962). These cells all showed a prominent endoplasmic reticulum and many mitochondria with variable numbers of vacuoles and dense bodies. Abundant interdigitated filopodia were seen in some sections (Fig. 7). In other areas these cells were separated by variable amounts of mature collagen fibres. Round deposits of dense, finely granular haemosiderin,

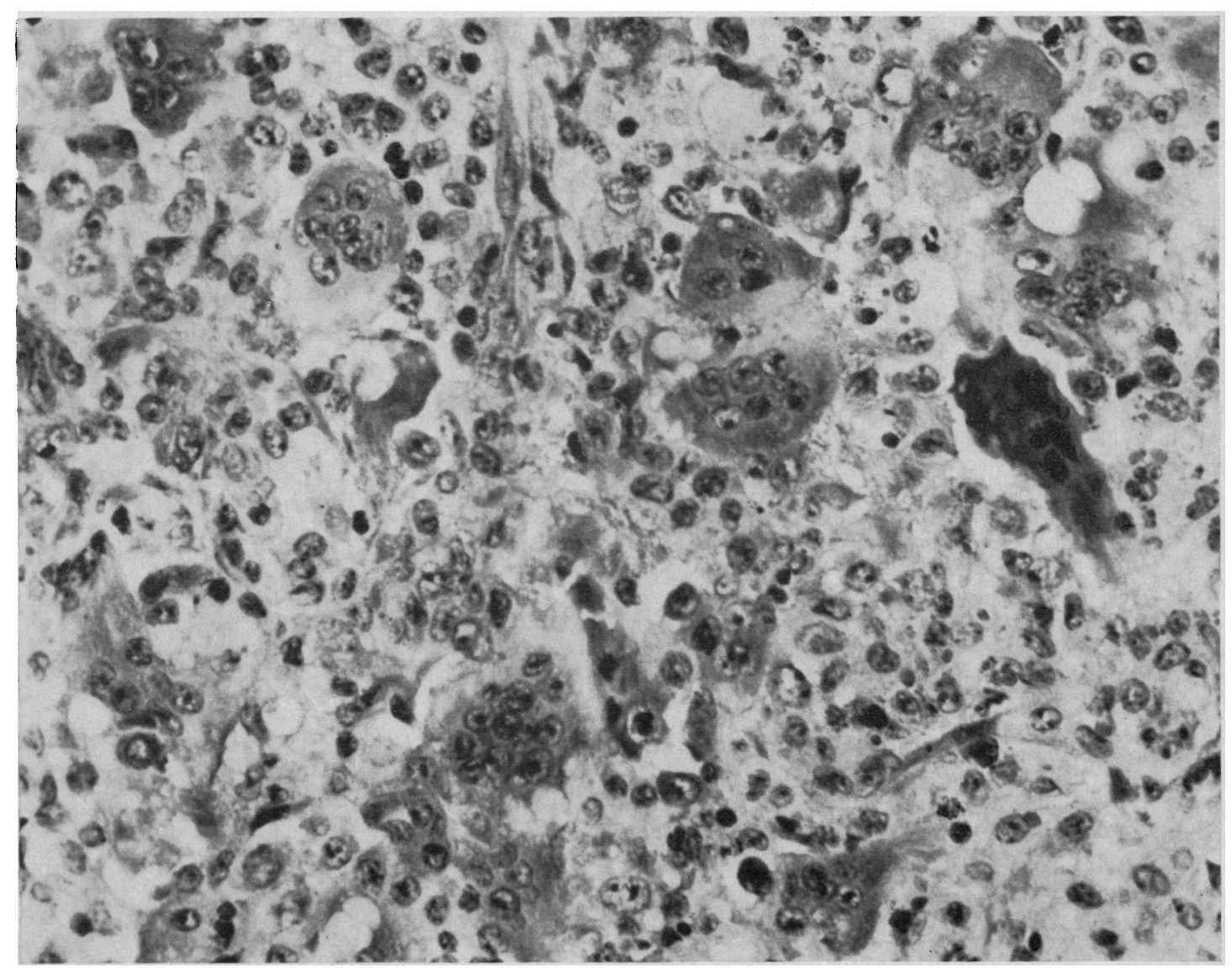

FIG. 3 Case 1. Surgical biopsy of tumorous swelling of the right third PIP joint showing a solid mass of large mononuclear cells and multinucleated giant cells. van Gieson. $\times 400$. 
FIG. 4 Case 2. Nodular swelling on the radial aspect of the left second PIP joint, interosseous muscle atrophy, and MCP joint swelling

membrane bound or lying free, were seen in the cytoplasm of intermediate type cells. Multinucleated cells showed 1 to 3 central nuclei with many mitochondria, central Golgi apparatus adjacent to the nuclei, moderate endoplasmic reticulum, and virtually no dense bodies (lysosomes) (Fig. 8). Many type B cells showed dilated endoplasmic reticulum containing amorphous material. Isolated foam cells were also seen and were characterized by numerous large, round membrane-bound electron lucent deposits with more dense material at the periphery, as described by Eisenstein (1968). Needle synovial biopsy of the knee showed fibrous synovium, 3 to 4 layers of synovial lining cells, and scattered infiltrations of lymphocytes and plasma cells. No giant cells or haemosiderin deposits were seen. Because the patient retained complete function of the left fourth PIP joint and it was surgically impossible to remove the tumour without amputating the finger, we decided to observe the patient.

After $2 \frac{1}{2}$ years of gold therapy satisfactory control of the articular symptoms had been obtained. Though the tumour showed progressive soft tissue growth, roentgenograms disclosed remineralization of the cystic areas of the proximal phalanx (Fig. 5B). At this time the tumour was removed and was found to arise from the left second flexor tendon sheath and to be attached to the capsule of the second PIP joint. Histopathological features were similar to the previous surgical biopsy (Fig. 6).
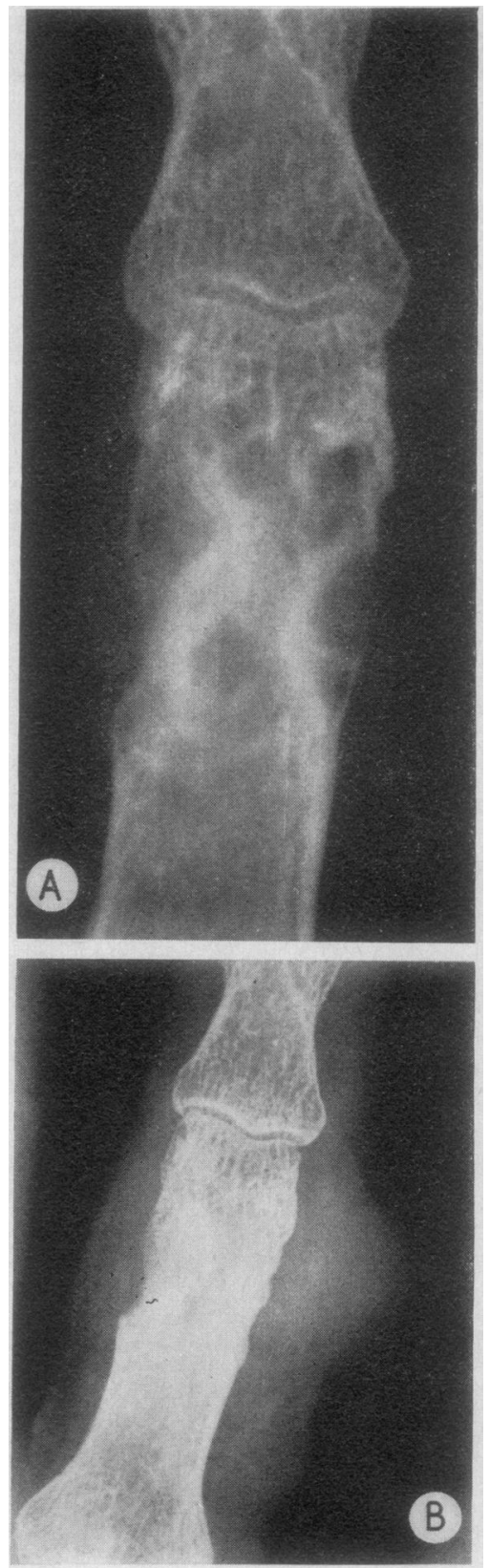

FIG. 5 Roentgenograms of Case 2. (A) Left second PIP joint showing polycystic and sclerotic areas in the proximal $\stackrel{\mathscr{S}}{+}$ phalanx. (B) The same joint taken after 2 years of gold $T$ therapy showing increasing soft tissue swelling and remineralization of the cystic areas

CASES 3-5

In the next 3 cases, which along with the first 2 are sum. marized in the Table, the histopathological diagnosis was established when the tumour was limited to the flexor tendons of the fingers without invasion of bone or joints. 


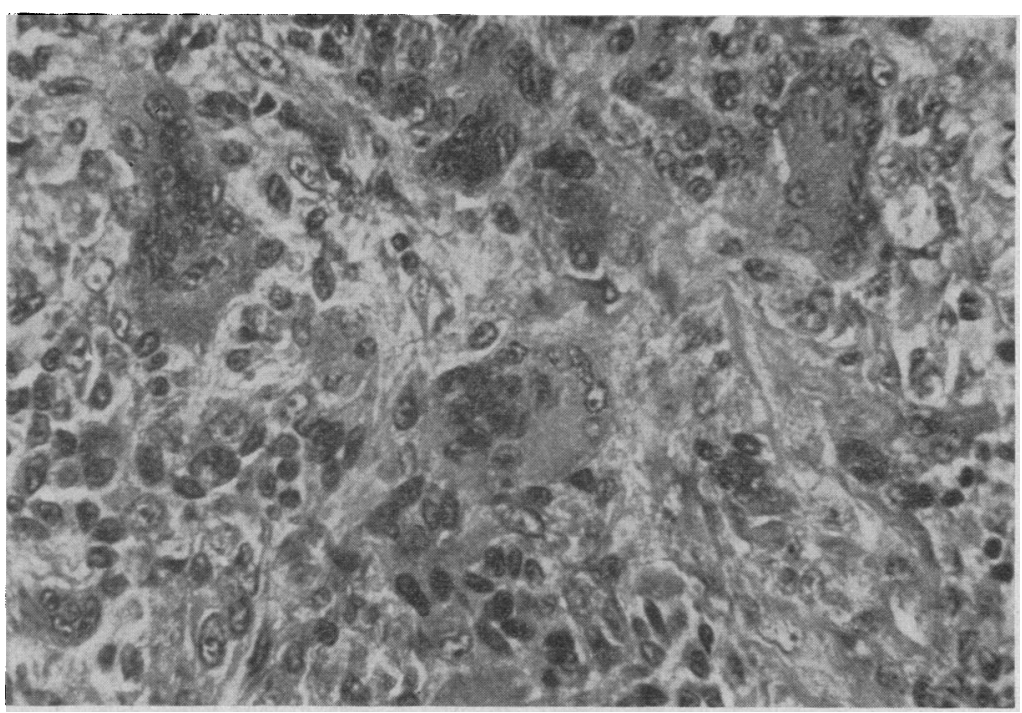

FIG. 6 Case 2. Surgical biopsy of the left second PIP joint showing a conglomerate of large mononuclear cells, multinucleated giant cells, and fibrous tissue. van Gieson $\times 400$

Case 3 A 59-year-old white woman who had a 3-year history of definite mild, polyarticular rheumatoid arthritis with severe joint involvement of the right knee. The synovial biopsy of the knee showed characteristic signs of rheumatoid synovitis including hyperplastic synovial lining cells, aggregates of plasma cells, lymphocytes, and lymphoid follicles with germinal centres. A nodular swelling was removed from the right third finger flexor tendon. The pathology report disclosed an unsuspected giant cell tumour of the tendon sheath. After this experience we recommended surgical exploration of the next two patients.

Case 4 A 40-year-old white woman with long-standing classical rheumatoid arthritis, who for 4 years had an irregular and firm nodule on her left fourth flexor tendon in close relationship to the MCP joint. Pathological studies revealed a giant cell tumour of the flexor tendon sheath; the lump was tightly attached to the joint capsule in its outer aspect. The synovial membrane of the tendon sheath and that of the fourth PIP joint showed typical rheumatoid synovitis.

Case 5 A 64-year-old white woman with classical RA of 10 years' duration developed a firm, slow growing, irregular nodule on the ulnar aspect of the proximal phalange of the left index finger in relationship to the flexor tendon sheath. Histopathological studies showed that the nodule was formed by a rich connective tissue stroma, fibroblasts, haemosiderin-loaded macrophages, foam cells, and giant cells.

\section{Discussion}

Giant cell tumours in the fingers have been infrequently recognized in patients with rheumatoid arthritis (Jimenez Diaz, Fernandez Criado, Navarro, Oliva, Gonzalez Elipe, and Culébras, 1967). In a series of 118 cases of giant cell tumour of the tendon

Table Giant cell tumours associated with rheumatoid arthritis in five patients

\begin{tabular}{|c|c|c|c|c|c|c|c|c|}
\hline \multirow[b]{2}{*}{$\begin{array}{l}\text { Case } \\
\text { no. }\end{array}$} & \multirow[b]{2}{*}{$\operatorname{Sex}$} & \multirow[b]{2}{*}{$\begin{array}{l}\text { Age } \\
(y r s)\end{array}$} & \multicolumn{2}{|c|}{ Rheumatoid arthritis } & \multirow{2}{*}{$\begin{array}{l}\text { Serum latex } \\
\text { fixation } \\
\text { test }\end{array}$} & \multicolumn{3}{|c|}{ Tendon sheath giant cell tumour } \\
\hline & & & $\begin{array}{l}\text { A.R.A. } \\
\text { classification }\end{array}$ & $\begin{array}{l}\text { Duration } \\
(y r s)\end{array}$ & & Site & $\begin{array}{l}\text { Duration } \\
\text { (mths) }\end{array}$ & Treatment \\
\hline 1 & $\mathbf{F}$ & 65 & Classical & 1 & $(-)$ & R 3rd PIP & 6 & Amputation of finger \\
\hline 2 & $\mathbf{F}$ & 60 & Classical & 10 & $1: 160$ & L 2nd PIP & 48 & $\begin{array}{l}\text { Resection after } 2 \text { yrs } \\
\text { gold therapy }\end{array}$ \\
\hline 3 & $\mathbf{F}$ & 59 & Definite & 3 & $(-)$ & $\begin{array}{l}\mathrm{R} \text { 3rd flexor } \\
\text { tendon }\end{array}$ & 1 & Resection \\
\hline 4 & $\mathbf{F}$ & 40 & Classical & 8 & $1: 320$ & $\begin{array}{l}\text { L 4th flexor } \\
\text { tendon }\end{array}$ & 48 & Resection \\
\hline 5 & $\mathbf{F}$ & 64 & Classical & 10 & $1: 160$ & $\begin{array}{l}\text { L 2nd flexor } \\
\text { tendon }\end{array}$ & 6 & Resection \\
\hline
\end{tabular}




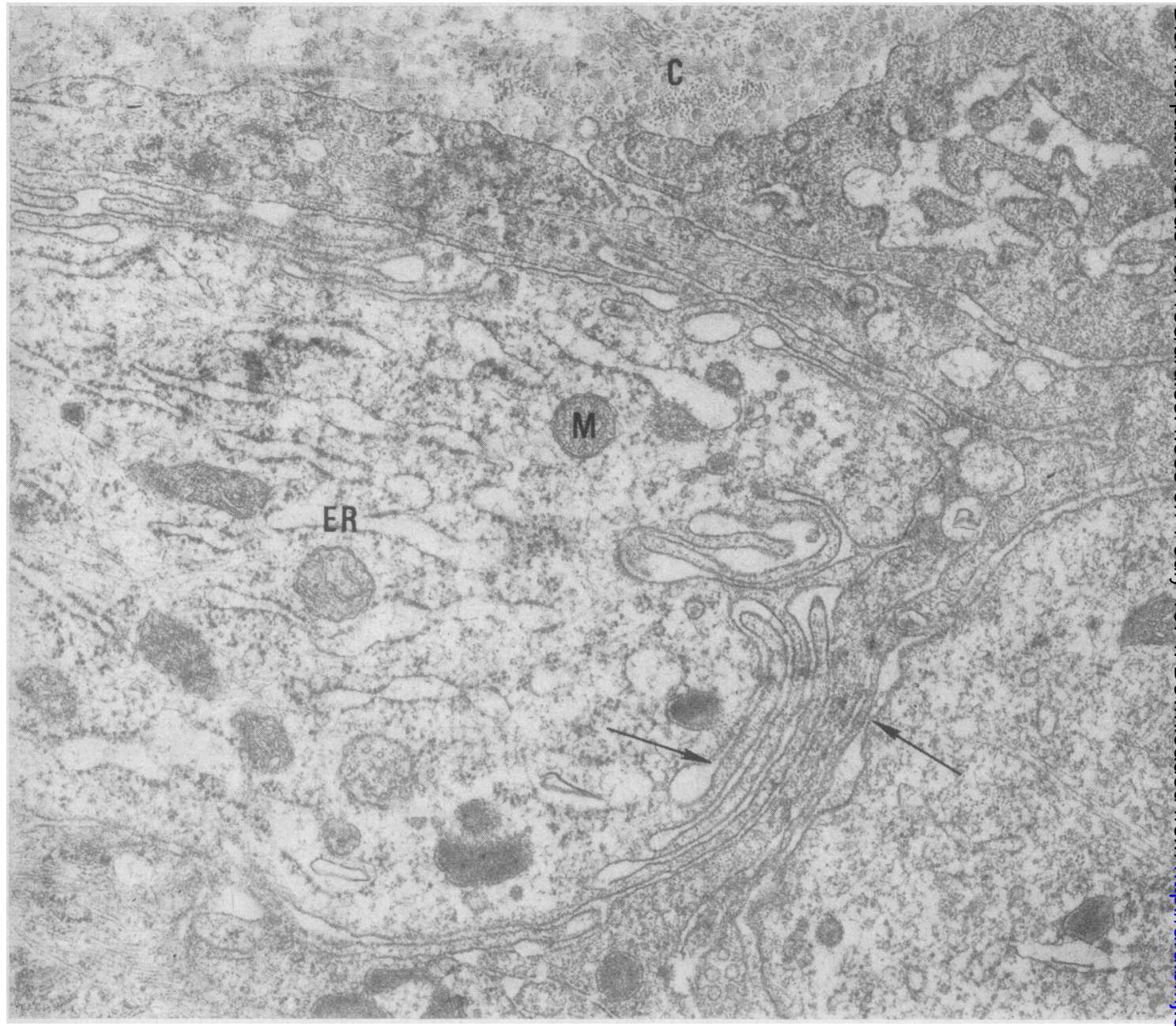

FIG. 7 (A) Electron micrograph showing long interdigitating processes (arrows) of tumour cells of Case 2. M=mitochondrion; ER = endoplasmic reticulum; $C=$ collagen. $\times 24,500$. (B) Apparent cytoplasmic communication between processes of two tumour cells at the arrows. $\times 32,150$

sheaths, 91 were localized to the hand, but only two patients had associated RA (Jones and others, 1969). This may be partly because some giant cell tumours are clinically confused with the very common inflammatory tendon sheath inflammation or with rheumatoid nodules. Most reported series describing hand tenosynovitis in RA have not mentioned the presence of giant cell tumour or giant cell reaction (Backhouse, Kay, Coomes, and Kates, 1971 ; Brewerton, 1957; Kellgren and Ball, 1950).

The fully developed giant cell tumours in the tendon sheaths of our patients differed clinically from rheumatoid tenosynovitis or synovitis by their slow growth, persistence, and greater size.

The 5 cases of RA associated with giant cell tumour of the tendon sheaths documented in this study raise the question about a relationship between the two processes. One possibility is that this association is the result of coincidence of two fairly common conditions. Giant cell tumours are the second most common tumours of the hand (Jones and others, 1969). Common causative factors, however, are suggested by Case 1 in whom the rheumatoid disease and the giant cell tumour started almost simultaneously, and both presented very accelerated destructive courses. Many features seen in giant cell tumours are also seen in typical rheumatoid synovial inflammation. These include giant cells and foam cells (Grimley and Sokoloff, 1966; Collins, 1949), iron deposition (Muirden and Senator, 1968), and monotonous proliferation of similar appearing cells (synovial lining cells). However, the giant cells with rich endoplasmic 


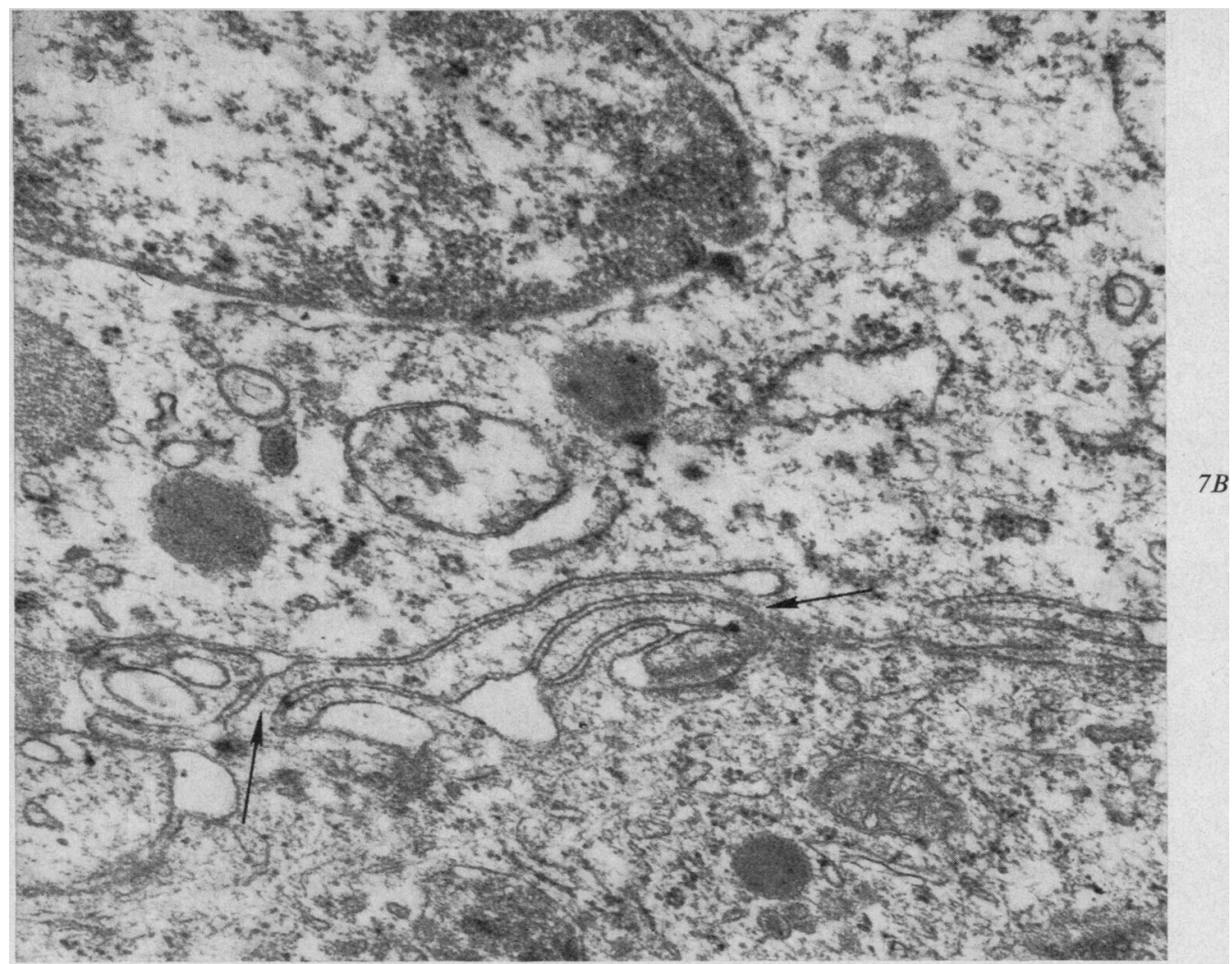

reticulum seen in our tumours clearly differ from the macrophage-like giant cells described in synovial membrane of RA (Grimley and Sokoloff, 1966). Ultrastructural features of the majority of tumour cells are those of type B or intermediate cells. Along with the foam cells, these are similar to the findings in other giant cell tumours in patients without rheumatoid arthritis (Eisenstein, 1968). Thus, we suspect that if there is any relation between rheumatoid synovial proliferation and the tumour it is more reasonable to postulate loss of control over proliferation of type B (synthetic) cells rather than overgrowth of the phagocytic cells. As described in the results, we saw many type B and intermediate cells with many interdigitations that could be in the process of forming giant cells in this fashion.

Other diseases that we considered in differential diagnosis included multicentric reticulohistiocytosis, a destructive type of arthritis resembling rheumatoid arthritis with nodules in skin, synovium, and bone formed by multinucleated giant cells and histiocytes loaded with lipid inclusions (Barrow and Holubar, 1969). In the five patients presented here the giant cell tumours were localized to the tendon sheaths of the hand. Pathological studies of a subcutaneous nodule in one revealed a typical rheumatoid nodule, and synovial biopsies performed in four patients showed variable degrees of inflammation with infiltration of lymphocytes and plasma cells without giant cells or foam cells. A variety of benign neoplasms such as glomus tumours, chondromas, and nerve sheath tumours may produce erosion of the juxta-articular bone. These must be considered in the differential diagnosis, as must gouty tophi or tuberculous osteitis: both conditions can induce severe destructive bone changes.

At present, no pathogenetic relationship between rheumatoid arthritis and giant cell tumour of tendon sheath or joint is demonstrable: their simultaneous occurrence appears to be coincidental. However, giant cell tumours must be included in the differential diagnosis of localized nodules and bone or joint destruction in the hands of patients with rheumatoid arthritis.

\section{Summary}

The presence of giant cell tumour of the joint or tendon sheath is documented in five patients with rheumatoid arthritis. The first patient presented with an invasive and destructive tumour of one PIP joint coincident with recent onset of severe erosive rheuma- 
FIG. 8 Electron micrograph of giant cell from tumour of Case 2. $N=$ nuclei; $M=$ mitochondrion; $E R=$ endoplasmic reticulum; $C=$ collagen; $G=$ golgi apparatus. $\times 14,150$

toid disease. In the other patients the rheumatoid arthritis preceeded by 1 to 10 years the appearance of the tumour in a PIP joint or in the flexor tendon sheaths of the hand. These tumour masses were all initially confused with either rheumatoid nodules or synovitis. Giant cell tumours must be included in the differential diagnosis of localized masses or bone

and joint destruction in patients with rheumatoid arthritis.

We gratefully acknowledge the technical assistance of $O$ Miss Janina Hmelewsky and Miss Gilda Clayburne. Drs. Joseph Hollander and Carl Brighton kindly reviewed the manuscript. This study was supported in part by the $\stackrel{\mathbb{D}}{\oplus}$ Barsumian Memorial Fund.

\section{References}

Backhouse, K. M., Kay, A. G. L., Coomes, E. N., AND Kates, A. (1971) Ann. rheum. Dis., 30, 236 (Tendon involvement in the rheumatoid hand)

Barland, P., Novikoff, A. B., ANd Hamerman, D. (1962) J. Cell Biol., 14, 207 (Electron microscopy of the human synovial membrane)

Barrow, M. V., AND Holubar, K. (1969) Medicine, 48, 287 (Multicentric reticulohistiocytosis: a review of 33 patients) 
Bennett, G. A. (1950) Proc. Inst. Med. Chicago, 18, 26 (Reactive and neoplastic changes in synovial tissues)

Brewerton, D. A. (1957) Ann. rheum. Dis., 16, 183 (Hand deformities in rheumatoid arthritis)

Byers, P. D., Cotton, R. E., Deacon, O. W., Lowy, M., Newman, P. H., Sissons, H. A., and Thompson, A. D. (1968) J. Bone Jt Surg., 50-B, 290 (The diagnosis and treatment of pigmented villonodular synovitis)

Collins, D. H. (1949) In 'The Pathology of Articular and Spinal Diseases', 179. Arnold, London

Eisenstein, R. (1968) J. Bone Jt Surg., 50A, 476 (Giant cell tumor of tendon sheath. Its histogenesis as studied in the electron microscope)

Galloway, J. D. B., Broders, A. C., AND Ghormley, R. (1940) Arch. Surg., 40, 485 (Xanthoma of tendon sheaths and synovial membranes: a clinical and pathologic study)

Grimley, P. M., ANd Sokoloff, L. (1966) Amer. J. Path., 49, 931 (Synovial giant cells in rheumatoid arthritis)

Jafre, H. L., Lichtenstern, L., AND Sutro, C. J. (1941) Arch. Path., 31, 731 (Pigmented villonodular synovitis, bursitis and tenosynovitis)

Jimenez-Diaz, C., Fernandez-Criado, M., Navarro, V., Oliva, H., Gonzalez Elipe, J., and Culébras, A. (1967) Rev. Rhum., 34, 11 (Sur une forme polyarticulaire de synovite villonodulaire pigmentaire. Polyarticular form of pigmented villonodular synovitis)

Jones, F. E., Soule, E. H., AND Coventry, M. B. (1969) J. Bone Jt. Surg., 51A, 76 (Fibrous xanthoma of synovium. Giant-cell tumor of tendon sheath, pigmented villonodular synovitis)

KARNovsKy, M. J. (1965) J. Cell Biol., 27, 137A, Abstract 270 (A formaldehyde-glutaraldehyde fixative of high osmolality for use in electron microscopy)

KAY, A. G. L. (1971) Ann. rheum. Dis., 30, 98 (The natural history of synovial hypertrophy in the rheumatoid hand)

Kellgren, J. H., AND Ball, J. (1950) Ibid., 9, 48 (Tendon lesions in rheumatoid arthritis. A clinico-pathological study)

Kinsella, T. D., Baum, J., AND Ziff, M. (1970) Arthr. and Rheum., 13, 734 (Studies of isolated synovial lining cells of rheumatoid and nonrheumatoid synovial membranes)

LaRmon, W. A. (1965) Med. Clin. N. Amer., 49, 141 (Pigmented villonodular synovitis)

Mutrden, K. D., and Senator, G. B. (1968) Ann. rheum. Dis., 27, 38 (Iron in the synovial membrane in rheumatoid arthritis and other joint disease)

RodnAN, G. D. (1966) Tumors of synovial joints, bursae and tendon sheaths', in 'Arthritis and Allied Conditions'. ed. J. L. Hollander, 7th ed., p. 1135. Lea and Febiger, Philadelphia

Ropes, M. W., Bennett, G. A., Cobb, S., Jacox, R., And Jessar, R. A. (1959) Ann. rheum. Dis., 18, 49 (Diagnostic criteria for rheumatoid arthritis; 1958 revision)

SCHUMACHER, H. R. (1968) Arthr. and Rheum., 11, 426 (The synovitis of pseudogout: electron microscopic observations)

—, AND KulKa, J. P. (1972) New Engl. J. Med., 286, 416 (Needle biopsy of the synovial membrane. Experience with the Parker-Pearson technic)

Singer, J. M., AND Plotz, C. M. (1956) Amer. J. Med., 21, 888 (The latex fixation test: application to the serologic diagnosis of rheumatoid arthritis)

Wright, C. J. E. (1951) Brit. J. Surg., 38, 257 (Benign giant cell synovioma: an investigation of 85 cases) 